\title{
p28GANK overexpression is associated with chemotherapy resistance and poor prognosis in ovarian cancer
}

\author{
GE YU ${ }^{1,2}, \mathrm{NA} \mathrm{LI}^{2}$, WEI WANG ${ }^{2}, \mathrm{MING} \mathrm{NIU}^{3}$ and XIAOLING FENG ${ }^{2}$ \\ ${ }^{1}$ Department of Gynecology, Harbin Medical University Cancer Hospital, Harbin, Heilongjiang 150081; \\ ${ }^{2}$ Department of Gynecology, The First Affiliated Hospital, Heilongjiang University of Chinese Medicine, \\ Harbin, Heilongjiang 150040; ${ }^{3}$ Department of Breast Surgery, Harbin Medical University \\ Cancer Hospital, Harbin, Heilongjiang 150081, P.R. China
}

Received November 15, 2017; Accepted February 11, 2019

DOI: $10.3892 / \mathrm{ol} .2019 .11081$

\begin{abstract}
The non-ATPase regulatory subunit 10 of the human $26 \mathrm{~S}$ proteasome (p28GANK) has been implicated in the tumorigenesis and progression of several types of malignant tumor. The aim of the present study was to detect the expression of p28GANK in ovarian cancer (OC) and investigate its association with the clinicopathological features and prognosis of OC. The expression levels of p28GANK were determined in 114 OC tissue samples and 30 normal ovarian tissue samples using immunohistochemistry. An association was observed between p28GANK overexpression and certain clinicopathological factors, including advanced International Federation of Gynecology and Obstetrics stage $(\mathrm{P}=0.042)$, residual tumor size $(\mathrm{P}=0.005)$ and response to chemotherapy $(\mathrm{P}<0.001)$. Furthermore, patients with high expression of p28GANK demonstrated worse overall survival (OS) and disease-free survival (DFS) rates compared with patients with low expression of p28GANK (both $\mathrm{P}<0.001$ ). Multivariate Cox regression analysis revealed that overexpression of p28GANK was an independent prognostic factor of OS and DFS in patients with $\mathrm{OC}(\mathrm{P}=0.013$ and $\mathrm{P}=0.001$, respectively). In summary, the current results indicate that $\mathrm{p} 28 \mathrm{GANK}$ may be a predictive marker and a therapeutic target for OC.
\end{abstract}

\section{Introduction}

Ovarian cancer (OC) has the highest mortality rate of all gynecological malignancies, with $\sim 14,240$ OC-associated mortalities reported in the USA in 2016 (1). Due to a lack of methods for early detection, almost $70 \%$ of patients present with an advanced

Correspondence to: Professor Xiaoling Feng, Department of Gynecology, The First Affiliated Hospital, Heilongjiang University of Chinese Medicine, 26 Heping Road, Xiangfang, Harbin, Heilongjiang 150040, P.R. China

E-mail: doctorfxl@163.com

Key words: 26S proteasome non-ATPase regulatory subunit 10, ovarian cancer, overall survival, disease-free survival stage of OC at diagnosis, resulting in a poor prognosis (2). Therefore, the identification of potential markers and improved understanding regarding the molecular mechanisms underlying OC may facilitate the development of early detection approaches and novel therapeutic strategies for patients with OC.

The 26S proteasome non-ATPase regulatory subunit 10 (p28GANK), which is localized on human chromosome Xq22.3, is a small protein of 226 amino acids containing 7 ankyrin repeats. This protein is a subunit of the $26 \mathrm{~S}$ proteasome that specifically interacts with the S6b ATPase of the 19S regulator (3-5). p28GANK promotes the hyperphosphorylation and degradation of retinoblastoma $(\mathrm{Rb})$, which releases the transcription factor E2F-1 from the Rb repressor complex. Furthermore, p28GANK binds to cyclin-dependent kinase 4 (CDK4) and prevents CDK4 inhibition by $16 \mathrm{NK} 4 \mathrm{a}$, which accelerates cell cycle progression (5). p28GANK binds to the E3 ubiquitin protein ligase MDM2, which enhances the ubiquitination and degradation of cellular tumor antigen p53 (6). In addition, it has also been demonstrated to regulate the nuclear factor- $\kappa \mathrm{B}(7)$, signal transducer and activator of transcription 3 (STAT3) (8) and protein kinase B (9) pathways. p28GANK serves an important role in cell metastasis, proliferation and autophagy in cancer $(8,10,11)$. However, to the best of our knowledge, there is limited understanding regarding its expression and clinical significance in $\mathrm{OC}$, which the present study aimed to investigate.

\section{Materials and methods}

Patients. OC tissue samples were obtained from who were surgically treated at the Third Affiliated Hospital of Harbin Medical University (Harbin, China) between January 1999 and 2006. The exclusion criteria were as follows: i) Multifocal carcinoma; ii) loss to follow-up [no overall survival (OS) follow-up and/or progression data]; and iii) previous history of cancer. Inclusion criteria were as follows: i) Presence of ovarian serous carcinoma confirmed by pathological examination; ii) complete basic clinical data; iii) absence of any prior treatment for cancer; iv) no serious complications or any other malignant disease; v) informed consent was provided by the patients and family members prior to treatment; and vi) complete cytoreductive surgery with no peri- or postoperative (within 45 days after surgery) mortality. The 
A

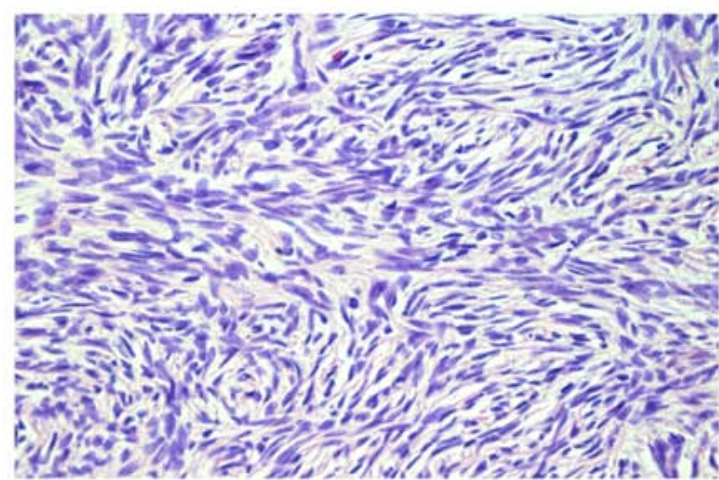

C

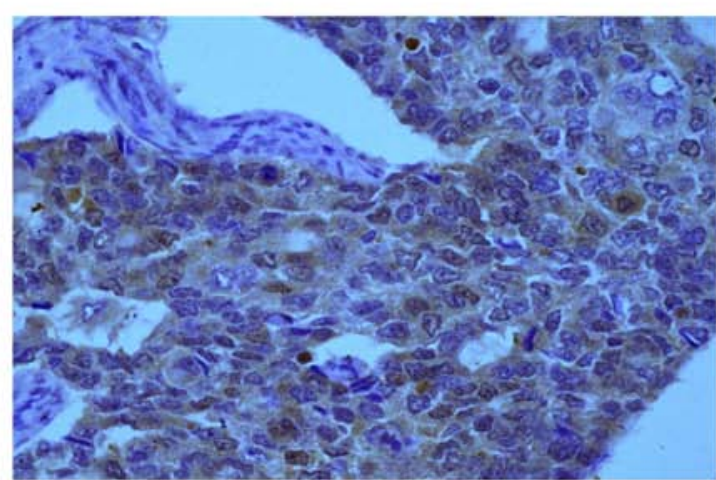

B

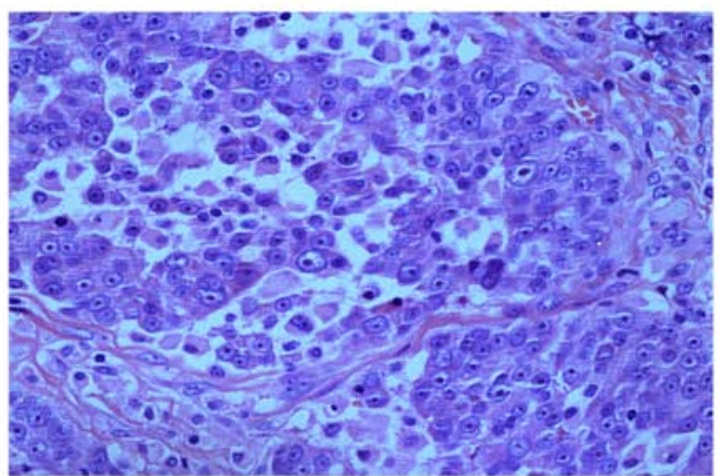

D

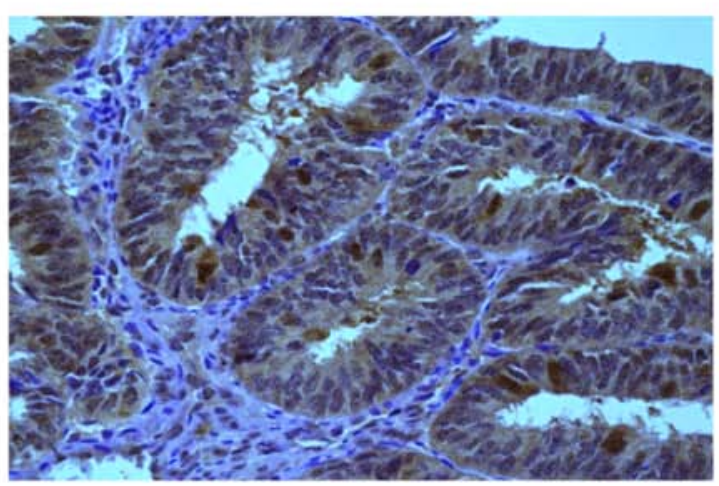

Figure 1. Immunostaining of p28GANK. Representative immunostaining images of p28GANK in (A) normal ovarian tissues, (B) ovarian cancer tissues with low expression, (C) ovarian cancer tissues with moderate expression and (D) ovarian cancer tissues with high expression. Magnification, $\mathrm{x} 400$. p28GANK, 26S proteasome non-ATPase regulatory subunit 10.

cohort for analysis that met the inclusion criteria consisted of 114 patients. The mean age of the patients was 49 years (range, 28-76 years). Additionally, normal ovarian tissue samples were acquired by endoscopy from non-tumor areas from 30 of the patients with $\mathrm{OC}$ enrolled in the study. All tissue specimens used in the current study were obtained with written informed consent from the patients. The study protocol was approved by the Ethics Committee of Harbin Medical University.

Immunohistochemistry (IHC). IHC was performed following standard procedures as described previously (12). All samples were confirmed to contain $>80 \%$ tumor cells by three pathologists. Formalin-fixed and paraffin-embedded tissue sections (4- $\mu \mathrm{m}$ thick) were dried out at $65^{\circ} \mathrm{C}$ for $2 \mathrm{~h}$. Samples were deparaffinized in xylene, and hydrated using a graded alcohol series (70\%, overnight; 80, 90 and $95 \%$ for $1 \mathrm{~h}$ each; and two separate $10 \mathrm{~min}$ treatments in $100 \%$. Subsequently, the tissue blocks were placed in xylene for 10 min until the specimen were transparent, after which the tissue blocks were placed in xylene + paraffin and at $60^{\circ} \mathrm{C}$ for $2 \mathrm{~h}$, to ensure the paraffin completely penetrated the tissue. The dissolved paraffin was poured into a metal frame, and the waxed tissue was placed in the center of the metal frame and left to cool. The tissue was sectioned into $5 \mu \mathrm{M}$ thick slices and placed in a dish with warm water. The unfolded tissue slices were placed on slides and dried at $60^{\circ} \mathrm{C} 4 \mathrm{~h}$. The sections were then treated with $3 \% \mathrm{H}_{2} \mathrm{O}_{2}$ at room temperature for $10 \mathrm{~min}$ and antigen retrieval was performed in citrate buffer $\left(\mathrm{pH} \mathrm{6.0)}\right.$ at $98^{\circ} \mathrm{C}$ for $10 \mathrm{~min}$. The tissue sections were incubated with anti-p28GANK mouse polyclonal antibodies (cat. no. ab238999; 1:200 dilu- tion; Abcam, Cambridge, UK) at $4^{\circ} \mathrm{C}$ overnight. Following washing in PBS, the samples were incubated with biotinylated secondary antibody (cat. no. 14709; 1:1,500 dilution; Cell Signaling Technology, Inc., Danvers, MA, USA) at room temperature for $30 \mathrm{~min}$ and developed with diaminobenzadine at room temperature for $5 \mathrm{~min}$. As a negative staining control, the primary antibody was replaced with PBS.

Each section was incubated in a 1:50 dilution of anti-p28GANK antibody. An optical microscope (magnification, $\mathrm{x} 400$ ) was used for assessment of IHC. The IHC reaction was quantified by multiplying the staining intensity by the percentage of positive tumor cells. In the cytoplasm, staining intensity was graded as 0 (no staining), 1 (weak staining), 2 (moderate staining) or 3 (strong staining). The percentage of the extent of reactivity was scored as follows: 0 (no positive tumor cells), $1(<10 \%), 2(10-50 \%)$ and $3(>50 \%)$. Each case was scored independently and in a blinded manner by two investigators. Final scores $\leq 4$ were regarded as low expression and the remainder were classified as high expression.

Follow up. All patients were followed until February 2015, unless they succumbed prior to this date. The OS time was defined as the interval from surgery to mortality or the date of the most recent follow-up. Progression-free survival (PFS) time was calculated from the date of surgery to the date of relapse, including proven local recurrence or distant metastasis, or the date of the most recent follow-up.

PrognoScan database analysis. The association between p28GANK expression and survival in OC was analyzed 
Table I. p28GANK expression in normal and ovarian cancer tissue samples.

\begin{tabular}{lccc}
\hline & \multicolumn{2}{l}{ p28GANK expression, $\mathrm{n}(\%)$} & \\
\cline { 2 - 3 } Category & Low & High & P-value \\
\hline Tissue type & & $<0.001$ \\
Normal & $20(66.7)$ & $10(33.3)$ & \\
Tumor & $42(36.8)$ & $72(63.2)$ & \\
\hline
\end{tabular}

p28GANK, 26S proteasome non-ATPase regulatory subunit 10 .

using the PrognoScan database (13) PrognoScan searches for associations between gene expression and patient prognosis, including OS and disease-free survival (DFS), across a large collection of publicly available cancer microarray datasets, were performed. The threshold was adjusted to a Cox P-value $<0.05$.

GEPIA database analysis. Gene Expression Profiling Interactive Analysis (GEPIA) (14) is a newly developed interactive web server for analyzing RNA sequencing expression data from The Cancer Genome Atlas (TCGA) database (15). The expression and survival analysis of p28GANK was performed using GEPIA online software version 1.0. OC and matched normal TCGA data and Genotype-Tissue Expression (GTEx) data were used for the expression analysis (16), and $\log _{2}(\mathrm{TPM}+1)$ was used for the log-scale.

Statistical analysis. Statistical analysis was performed using SPSS (version 18.0; SPSS Inc., Chicago, IL, USA). A Mann Whitney-U test was used to compare two independent non-parametric samples. $\chi^{2}$ tests were used to assess associations between p28GANK expression level and clinicopathological features. Kaplan-Meier survival curves and log-rank tests were used for survival analysis. Prognostic factors were evaluated by univariate and multivariate analyses using Cox proportional hazard regression models. $\mathrm{P}<0.05$ was considered to indicate a statistically significant difference. Kaplan-Meier survival analysis was used on the Gene Expression Omnibus dataset (GSE26712) using PrognoScan (12). Histological grading was based on the World Health Organization Histological grading system (17).

\section{Results}

p28GANK expression in OC and normal tissues. The expression level of p28GANK was higher in the cytoplasm of cancer cells compared with normal tissues (Fig. 1). In the 30 normal controls, only 10 samples $(33.3 \%)$ exhibited a positive p28GANK cytoplasmic staining. By contrast, of the 114 OC specimens, positive cytoplasmic expression of p28GANK was identified in 72 samples (63.2\%; $\mathrm{P}<0.001$; Table I).

p28GANK overexpression is associated with clinicopathological features. The association between the protein expression of p28GANK and clinicopathological variables
Table II. Association between p28GANK expression and clinicopathological factors and of samples from patients with ovarian cancer $(n=114)$.

\begin{tabular}{|c|c|c|c|c|}
\hline \multirow[b]{2}{*}{ Variable } & \multirow[b]{2}{*}{$\mathrm{n}$} & \multicolumn{2}{|c|}{$\begin{array}{c}\text { p28GANK } \\
\text { expression, n }(\%)\end{array}$} & \multirow[b]{2}{*}{ P-value } \\
\hline & & Low & High & \\
\hline Age, years & & & & 0.598 \\
\hline$<50$ & 36 & $12(33.3)$ & $24(66.7)$ & \\
\hline$\geq 50$ & 78 & $30(38.5)$ & $48(61.5)$ & \\
\hline $\begin{array}{l}\text { Omental } \\
\text { metastasis }\end{array}$ & & & & 0.064 \\
\hline No & 27 & $14(51.9)$ & $13(48.1)$ & \\
\hline Yes & 87 & $28(32.2)$ & $59(67.8)$ & \\
\hline $\begin{array}{l}\text { Lymph node } \\
\text { metastasis }\end{array}$ & & & & 0.765 \\
\hline No & 101 & $38(37.6)$ & $63(62.4)$ & \\
\hline Yes & 13 & $4(30.8)$ & $9(69.2)$ & \\
\hline FIGO stage & & & & $0.042^{\mathrm{a}}$ \\
\hline $\mathrm{I} / \mathrm{II}$ & 17 & $10(58.8)$ & 7 (41.2) & \\
\hline III/IV & 97 & $32(33.0)$ & $65(67.0)$ & \\
\hline $\begin{array}{l}\text { Histological } \\
\text { grade }\end{array}$ & & & & 0.553 \\
\hline G1 & 28 & $9(32.1)$ & 19 (67.9) & \\
\hline G2/G3 & 86 & $33(38.4)$ & 53 (61.6) & \\
\hline $\begin{array}{l}\text { Residual } \\
\text { disease, } \mathrm{cm}\end{array}$ & & & & $0.005^{\mathrm{a}}$ \\
\hline$\leq 2$ & 98 & $41(41.8)$ & $57(50.0)$ & \\
\hline$>2$ & 16 & $1(6.3)$ & $15(93.8)$ & \\
\hline Ascites & & & & 0.841 \\
\hline No & 34 & $13(38.2)$ & $21(61.8)$ & \\
\hline Yes & 80 & $29(36.3)$ & $51(63.8)$ & \\
\hline $\mathrm{CA}-125, \mathrm{U} / \mathrm{ml}$ & & & & 1.000 \\
\hline$\leq 35$ & 12 & $4(33.3)$ & $8(66.7)$ & \\
\hline$>35$ & 102 & $38(37.3)$ & $64(62.7)$ & \\
\hline $\begin{array}{l}\text { Response to } \\
\text { chemotherapy }\end{array}$ & & & & $<0.001^{\mathrm{a}}$ \\
\hline Resistant & 39 & $5(12.8)$ & $34(87.2)$ & \\
\hline Sensitive & 75 & $37(49.3)$ & $38(50.7)$ & \\
\hline $\begin{array}{l}\text { Histological } \\
\text { classification }\end{array}$ & & & & 0.893 \\
\hline Serous & 71 & $30(42.3)$ & $41(57.7)$ & \\
\hline Mucinous & 18 & $6(33.3)$ & $12(66.7)$ & \\
\hline Endometrioid & 20 & $9(45.0)$ & $11(55.0)$ & \\
\hline Clear cell & 5 & $2(40.0)$ & $3(60.0)$ & \\
\hline
\end{tabular}

${ }^{\mathrm{a}} \mathrm{P}<0.05$. p28GANK, 26S proteasome non-ATPase regulatory subunit 10; FIGO, International Federation of Gynecology and Obstetrics; CA-125, cancer antigen 125 .

of OC are presented in Table II. p28GANK expression was significantly associated with the International Federation 

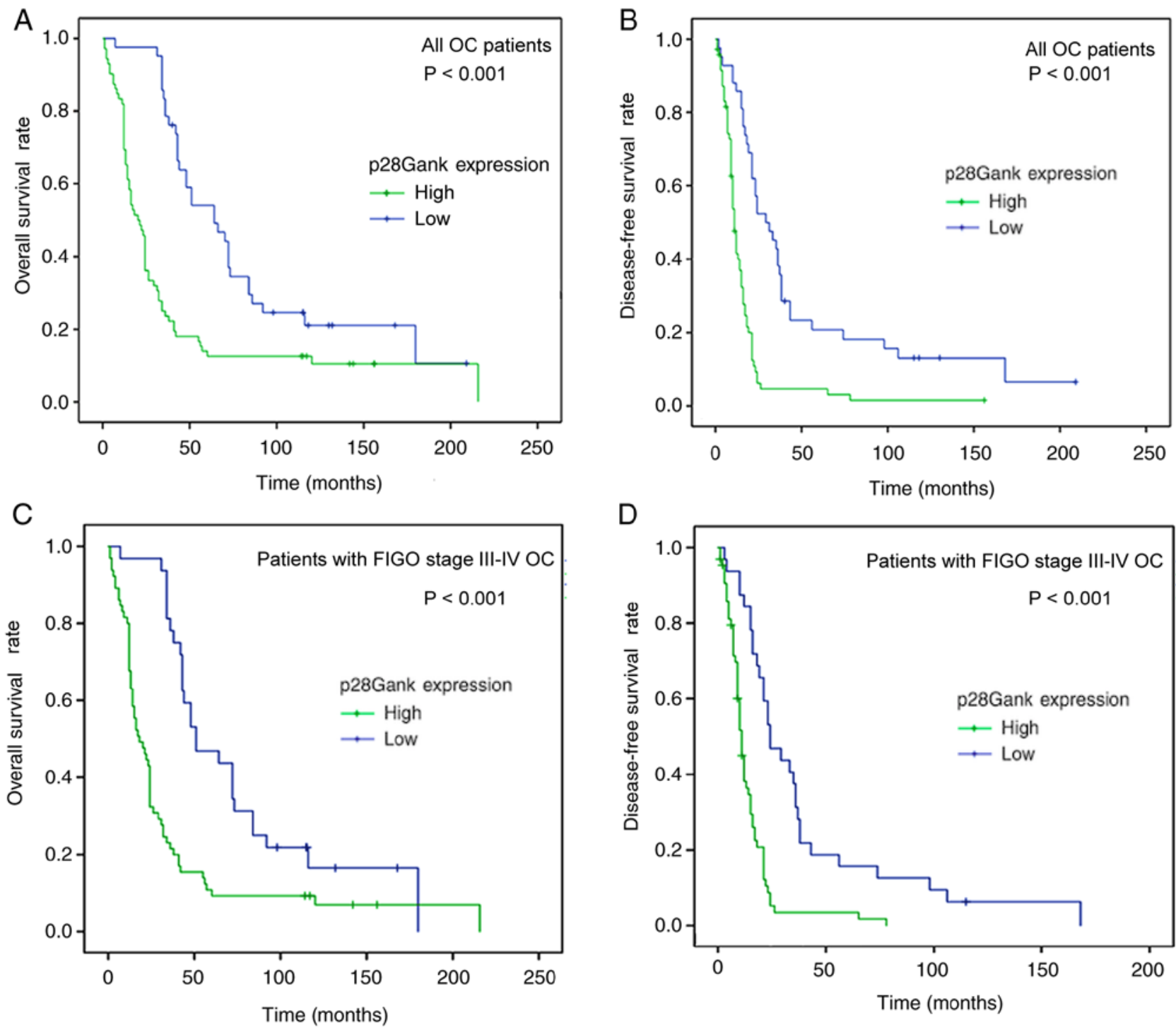

Figure 2. OS and DFS analysis for patients with OC with high and low p28GANK expression. (A) OS and (B) DFS rate for all cases of OC; (C) OS and (D) DFS rate for FIGO stage III-IV OC cases. All P<0.001. OS, overall survival; DFS, disease-free survival; OC, ovarian cancer; p28GANK, 26S proteasome non-ATPase regulatory subunit 10; FIGO, International Federation of Gynecology and Obstetrics.

of Gynecology and Obstetrics (FIGO) stage (18) ( $\mathrm{P}=0.042$ ), residual tumor size $(\mathrm{P}=0.005)$ and response to chemotherapy $(\mathrm{P}<0.001)$. No significant associations were identified between p28GANK expression and the other clinicopathological factors.

Association between p28GANK expression and survival time of patients with $O C$. The 5-year survival curves stratified by p28GANK expression are presented in Fig. 2. p28GANK expression was revealed to be significantly associated with OS $(\mathrm{P}<0.001)$ and DFS $(\mathrm{P}<0.001)$. A high expression level of p28GANK was associated with worse OS and DFS times for patients with OC. In addition, a FIGO-stratified analysis of all patients was performed according to the level of p28GANK expression. The results revealed that high expression of p28GANK was associated with DFS and OS in patients with FIGO III and IV OC (both $\mathrm{P}<0.001$ ).

The Kaplan-Meier survival analysis demonstrated that patients with high expression of p28GANK had significantly shorter DFS $(\mathrm{P}=0.038)$ and $\mathrm{OS}(\mathrm{P}=0.037)$ times using the Gene Expression Omnibus dataset (GSE26712) from PrognoScan (12) (Fig. 3). It was identified that p28GANK had no significant impact on and DFS $(\mathrm{P}=0.18)$ and $\mathrm{OS}$ time ( $\mathrm{P}=0.31$; Fig. 4).

Univariate and multivariate analyses of prognostic variables in patients with OC. Using univariate analysis, OS and DFS times were revealed to be significantly associated with high p28GANK expression (both $\mathrm{P}<0.001$ ), omental metastasis $(\mathrm{P}=0.011$ and $\mathrm{P}=0.001$, respectively), FIGO stage $(\mathrm{P}=0.007$ and $\mathrm{P}=0.005$, respectively), residual tumor size (both $\mathrm{P}<0.001$ ) and response to chemotherapy (both $\mathrm{P}<0.001$ ) (Table III).

The multivariate analysis revealed that high expression of p28GANK $(\mathrm{P}=0.013)$, residual tumor size $(\mathrm{P}<0.010)$ and response to chemotherapy $(\mathrm{P}=0.015)$ were independent prognostic factors for OS in patients with OC (Table IV). Furthermore, it indicated that high expression of p28GANK $(\mathrm{P}=0.001)$, histological grade $(\mathrm{P}=0.010)$, residual tumor size 

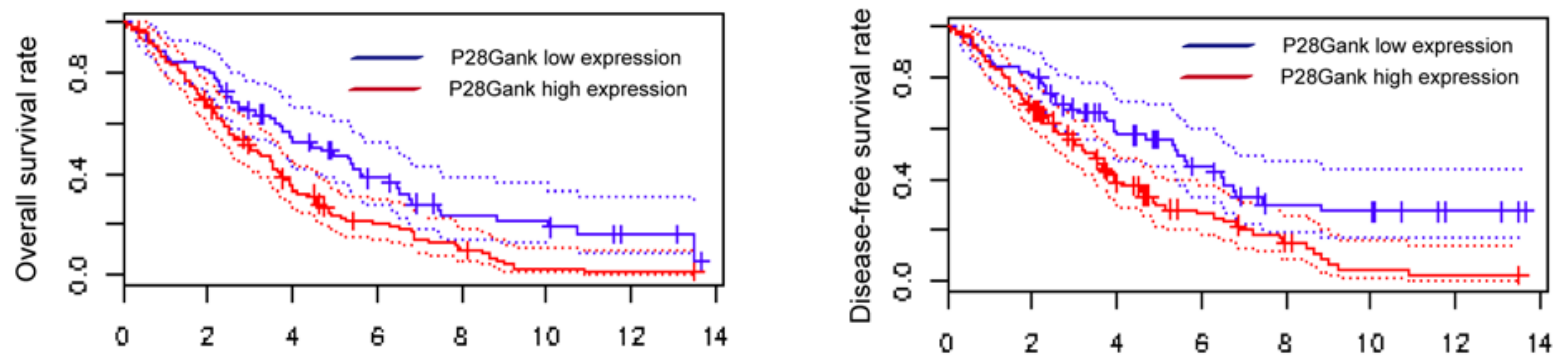

Figure 3. PrognoScan analysis of the OS and DFS times for patients with OC with high and low p28GANK expression. OS $(\mathrm{P}=0.037)$ and $\mathrm{DFS}$ rate $(\mathrm{P}=0.038)$ for all cases of OC. Dashed lines indicate the 95\% confidence interval. OS, overall survival; DFS, disease-free survival; OC, ovarian cancer; p28GANK, 26S proteasome non-ATPase regulatory subunit 10.

A

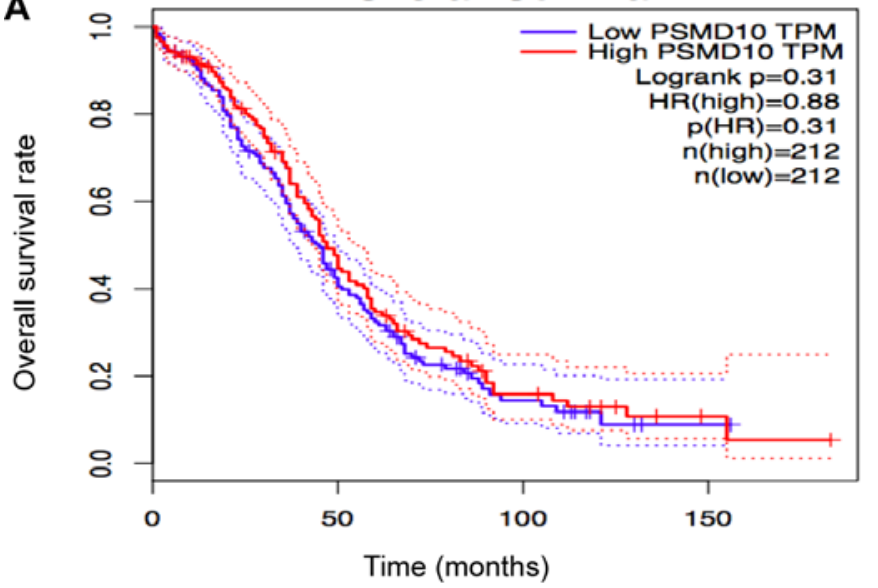

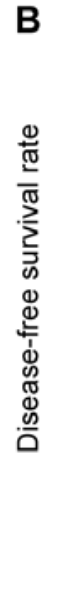

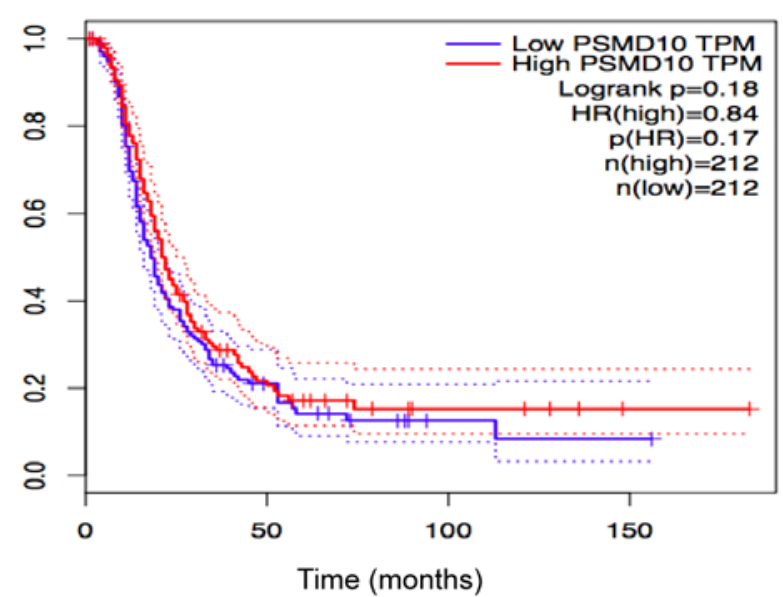

Figure 4. Analysis of OS and DFS times in ovarian cancer by Gene Expression Profiling Interactive Analysis. p28GANK expression was not associated with (A) OS (P=0.31) and (B) DFS (P=0.18). Dashed lines indicate the 95\% confidence interval. OS, overall survival; DFS, disease-free survival; p28GANK, 26S proteasome non-ATPase regulatory subunit 10; HR, hazard ratio; PSMD10, proteasome 26S subunit non-ATPase 1; TPM, transcript per million.

$(\mathrm{P}=0.009)$ and response to chemotherapy $(\mathrm{P}<0.001)$ were independent prognostic factors for DFS time in these patients (Table IV).

\section{Discussion}

The present study first analyzed the expression levels of p28GANK by IHC, revealing that it was higher in OC tissues compared with normal tissues. This finding is consistent with the results of previous studies (19).

A high p28GANK expression level has also been reported in several other types of cancer, including lung cancer, pancreatic cancer, colorectal cancer, esophageal squamous cell carcinoma, mammary carcinoma, endometrial carcinoma and hepatocellular carcinoma $(10,12,20-24)$

To further characterize the clinical prognostic implications of p28GANK, the present study analyzed the associations between 28GANK expression and the clinicopathological features and prognosis of patients with OC. The IHC results indicated significant associations between the expression of p28GANK and FIGO stage, residual disease and response to cisplatin-based chemotherapy. In addition, a significant association was revealed between the expression of p28GANK and poor prognosis for OC.

Chen et al (19) identified that a high expression level of p28GANK was positively associated with clinical stage and serum cancer antigen 125 levels, and negatively associated with tumor grade. Furthermore, high levels of p28GANK expression were associated with a poor prognosis and early relapse. In addition, a high expression level of p28GANK has been demonstrated to be associated with primary tumor, lymph node metastasis, clinical stage and poor prognosis in esophageal squamous cell carcinoma (22). In breast cancer, p28GANK overexpression has been associated with lymph node metastasis. Knockdown of p28GANK has been reported to inhibit tumor metastases to the lungs in animal models (23). Furthermore, p28GANK expression was revealed to be significantly higher in cases of hepatocellular carcinoma with increased tumor size and distant metastases (8). A similar observation has also been reported for colorectal cancer (21). In summary, these findings indicate a significant role of p28GANK in tumor metastasis and progression.

Higashitsuji et al (4) first identified p28GANK as an oncogenic protein that is overexpressed in hepatocellular carcinoma. This protein controls the phosphorylation of $\mathrm{Rb}$ by $\mathrm{CDK} 4$ and promotes the ubiquitination of $\mathrm{p} 53$ by MDM2 $(3,6)$. Man et al $(10)$ revealed that $\mathrm{p} 28 \mathrm{GANK}$ serves an essential role in Ras-initiated tumorigenesis in human lung cancer. It may decrease cancer cell focal adhesions by regulating the activity of Ras-related $\mathrm{C} 3$ botulinum toxin substrate 1 , resulting in metastasis (23). p28GANK 
Table III. Univariate and multivariate analyses for overall survival.

\begin{tabular}{|c|c|c|c|c|c|c|}
\hline \multirow[b]{2}{*}{ Variable } & \multicolumn{3}{|c|}{ Univariate analysis } & \multicolumn{3}{|c|}{ Multivariate analysis } \\
\hline & HR & $95 \% \mathrm{CI}$ & P-value & HR & $95 \% \mathrm{CI}$ & P-value \\
\hline Age, years (<50 vs. $\geq 50)$ & 1.353 & $0.867-2.113$ & 0.183 & 1.052 & $0.660-1.676$ & 0.832 \\
\hline Omental metastasis (no vs. yes) & 1.926 & $1.163-3.190$ & $0.011^{\mathrm{a}}$ & 1.271 & $0.603-2.682$ & 0.528 \\
\hline $\begin{array}{l}\text { Lymph node metastasis } \\
\text { (absent vs. present) }\end{array}$ & 1.130 & $0.617-2.071$ & 0.692 & 1.399 & $0.700-2.797$ & 0.342 \\
\hline FIGO stage (I/ II vs. III/ IV) & 2.480 & $1.285-4.787$ & $0.007^{\mathrm{a}}$ & 1.434 & $0.558-3.687$ & 0.454 \\
\hline $\begin{array}{l}\text { Histological grade } \\
\text { (G1 vs. G2/G3) }\end{array}$ & 1.156 & $0.718-1.862$ & 0.550 & 1.622 & $0.972-2.706$ & 0.064 \\
\hline Residual disease, $\mathrm{cm}(\leq 2$ vs. $>2$ ) & 6.715 & $3.748-12.032$ & $<0.001^{\mathrm{a}}$ & 2.408 & $1.237-4.687$ & $0.010^{\mathrm{a}}$ \\
\hline Ascites (no vs. yes) & 1.464 & $0.938-2.285$ & 0.093 & 1.184 & $0.729-1.922$ & 0.495 \\
\hline CA- $125, \mathrm{U} / \mathrm{ml}(\leq 35$ vs. $>35)$ & 1.125 & $0.564-2.243$ & 0.739 & 0.794 & $0.379-1.665$ & 0.542 \\
\hline $\begin{array}{l}\text { Response to chemotherapy } \\
\text { (resistant vs. sensitive) }\end{array}$ & 0.202 & $0.130-0.315$ & $<0.001^{\mathrm{a}}$ & 0.276 & $0.161-0.472$ & $<0.001^{\mathrm{a}}$ \\
\hline p28GANK (low vs. high) & 2.535 & $1.650-3.895$ & $<0.001^{\mathrm{a}}$ & 1.818 & $1.137-2.908$ & $0.013^{\mathrm{a}}$ \\
\hline
\end{tabular}

${ }^{\text {a }}<<0.05$. HR, hazard ratio; CI, confidence interval; FIGO, International Federation of Gynecology and Obstetrics; CA-125, cancer antigen 125; p28GANK, 26S proteasome non-ATPase regulatory subunit 10 .

Table IV. Univariate and multivariate analyses for disease-free survival.

\begin{tabular}{|c|c|c|c|c|c|c|}
\hline \multirow[b]{2}{*}{ Variable } & \multicolumn{3}{|c|}{ Univariate analysis } & \multicolumn{3}{|c|}{ Multivariate analysis } \\
\hline & HR & $95 \%$ CI & $\mathrm{P}$-value & HR & $95 \% \mathrm{CI}$ & P-value \\
\hline Age, years (<50 vs. $\geq 50)$ & 1.184 & $0.773-1.813$ & 0.438 & 0.982 & $0.632-1.523$ & 0.934 \\
\hline Omental metastasis (no vs. yes) & 2.286 & $1.389-3.761$ & $0.001^{\mathrm{a}}$ & 1.735 & $0.806-3.738$ & 0.159 \\
\hline $\begin{array}{l}\text { Lymph node metastasis } \\
\text { (absent vs. present) }\end{array}$ & 0.960 & $0.535-1.721$ & 0.890 & 0.865 & $0.444-1.683$ & 0.699 \\
\hline FIGO stage (I/II vs. III/IV) & 2.395 & $1.301-4.409$ & $0.005^{\mathrm{a}}$ & 1.036 & $0.418-2.564$ & 0.940 \\
\hline $\begin{array}{l}\text { Histological grade } \\
\text { (G1 vs. G2/G3) }\end{array}$ & 1.305 & $0.810-2.101$ & 0.274 & 1.962 & $1.174-3.278$ & $0.010^{\mathrm{a}}$ \\
\hline $\begin{array}{l}\text { Residual disease, } \\
\mathrm{cm}(\leq 2 \text { vs. }>2)\end{array}$ & 7.351 & $3.980-13.577$ & $<0.001^{\mathrm{a}}$ & 2.709 & $1.277-5.747$ & $0.009^{\mathrm{a}}$ \\
\hline Ascites (no vs. yes) & 1.412 & $0.921-2.165$ & 0.114 & 1.077 & $0.676-1.718$ & 0.754 \\
\hline CA-125, U/ml ( $\leq 35$ vs. $>35)$ & 1.579 & $0.792-3.147$ & 0.194 & 1.443 & $0.676-3.080$ & 0.343 \\
\hline $\begin{array}{l}\text { Response to chemotherapy } \\
\text { (resistant vs. sensitive) }\end{array}$ & 0.013 & $0.003-0.053$ & $<0.001^{\mathrm{a}}$ & 0.014 & $0.003-0.061$ & $<0.001^{\mathrm{a}}$ \\
\hline p28GANK (low vs. high) & 3.126 & $2.027-4.821$ & $<0.001^{\mathrm{a}}$ & 2.390 & $1.459-3.914$ & $0.001^{\mathrm{a}}$ \\
\hline
\end{tabular}

${ }^{\mathrm{a}} \mathrm{P}<0.05$. HR, hazard ratio; CI, confidence interval; FIGO, International Federation of Gynecology and Obstetrics; CA-125, cancer antigen 125; p28GANK, 26S proteasome non-ATPase regulatory subunit 10.

promotes tumor growth and metastasis in hepatocarcinogenesis via the phosphoinositide 3-kinase (9), STAT3 (8) and $\beta$-catenin (11) signaling pathways. Further investigation has confirmed that overexpression of p28GANK enhances the epithelial-mesenchymal transition, which is defined as the switching of polarized epithelial cells to a migratory fibroblastoid phenotype, strengthening matrix metalloproteinase 2 activity, and increasing vascular endothelial growth factor expression $(8,9)$. Therefore, p28GANK may promote cancer metastasis in numerous ways.

Patients with OC have been treated with carboplatin since 1989 (25). To the best of our knowledge, the present study is the first to report that p28GANK overexpression was associated with the response to platinum-based chemotherapy and the OS time of patients with OC. Accumulating data suggest that cancer stem cells (CSCs) exhibit a higher 
capacity for self-renewal and chemoresistance. Sun et al (26) identified that p28GANK mediates the dedifferentiation of hepatocytes via a hepatocyte nuclear factor $4 \alpha$-dependent mechanism. The decrease in p28GANK levels leads to a significant decrease in the proportion of CSCs and the degradation of octamer-binding transcription factor 4 in hepatoma cells (27). p28GANK has also been reported to be significantly associated with prominin-1 and Nanog in colorectal cancer (28). These data suggest that p28GANK may stimulate cancer cell stemness, resulting in resistance to cisplatin chemotherapy.

A previous study suggested that p28GANK inhibits apoptosis in hepatocellular carcinoma cells by enhancing the adaptive response and endoplasmic reticulum chaperone $\mathrm{BiP}$ expression under endoplasmic reticulum stress conditions (29). Furthermore, it increases resistance to apoptosis and enhances autophagy with sorafenib treatment (30). In summary, these findings indicate that p28GANK may be a therapeutic target for OC and a p28GANK inhibitor is likely to enhance the effects of cisplatin chemotherapy.

Chen et al (19) identified that p28GANK can promote OC cell proliferation. Consistent with this study, the present findings revealed that high expression of p28GANK was associated with FIGO stage and drug resistance. Therefore, p28GANK may promote tumor progression by enhancing resistance to treatment and may be a valuable therapeutic target.

In conclusion, the current study demonstrated high expression levels of p28GANK in OC. This expression was associated with FIGO stage, residual tumor size, response to chemotherapy, and poor OS and DFS. The present results highlight the importance of p28GANK in the progression of $\mathrm{OC}$, and suggest that it may be a potential prognostic marker and therapeutic target for the improvement of OC clinical management.

\section{Acknowledgements}

Not applicable.

\section{Funding}

The present study was part of the Program on the Clinical Study of Chinese Medicine funded by the National Natural Science Foundation of China (grant no. 81373673). The present study was also supported by Heilongjiang Health and Family Planning Commission Foundation (grant no. 2016-085), Heilongjiang Postdoctoral Foundation, China (grant no. LBH-Z16246) and Innovation Scientific Research Fund of Harbin Medical University (grant no. 2017LCZX81).

\section{Availability of data and materials}

The datasets used and/or analyzed during the current study are available from the corresponding author on reasonable request.

\section{Authors' contributions}

XF supervised the entire study and participated in study design and coordination. GY, NL and WW performed the experi- ments and statistical analysis, and drafted the manuscript. MN performed the statistical analysis and article revision. All authors read and approved the final manuscript.

\section{Ethics approval and consent to participate}

The present study was approved by the Research Ethics Committee of Harbin Medical University Cancer Hospital (Harbin, China). Written informed consent was obtained from all patients involved in the study.

\section{Patient consent for publication}

Not applicable.

\section{Competing interests}

The authors declare that they have no competing interests.

\section{References}

1. DeSantis CE, Siegel RL, Sauer AG, Miller KD, Fedewa SA, Alcaraz KI and Jemal A: Cancer statistics for African Americans, 2016: Progress and opportunities in reducing racial disparities. CA Cancer J Clin 66: 290-308, 2016.

2. Tørring ML, Falborg AZ, Jensen H, Neal RD, Weller D, Reguilon I; ICBP Working Group, Menon U and Vedsted P: Advanced-stage cancer and time to diagnosis: An international cancer benchmarking partnership (ICBP) cross-sectional study. Eur J Cancer Care (Engl): May 22, 2019 (Epub ahead of print).

3. Dawson S, Apcher S, Mee M, Higashitsuji H, Baker R, Uhle S, Dubiel W, Fujita J and Mayer RJ: Gankyrin is an ankyrin-repeat oncoprotein that interacts with CDK4 kinase and the S6 ATPase of the 26 S proteasome. J Biol Chem 277: 10893-10902, 2002.

4. Higashitsuji H, Itoh K, Nagao T, Dawson S, Nonoguchi K, Kido T, Mayer RJ, Arii S and Fujita J: Reduced stability of retinoblastoma protein by gankyrin, an oncogenicankyrin-repeat protein overexpressed in hepatomas. Nat Med 6: 96-99, 2000.

5. Krzywda S, Brzozowski AM, Higashitsuji H, Fujita J, Welchman R, Dawson S, Mayer RJ and Wilkinson AJ: The crystal structure of gankyrin, an oncoprotein found in complexes with cyclin-dependent kinase 4 , a 19 S proteasomal ATPase regulator, and the tumor suppressors $\mathrm{Rb}$ and $\mathrm{p} 53$. J Biol Chem 279: 1541-1545, 2004.

6. Higashitsuji H, Higashitsuji H, Itoh K, Sakurai T, Nagao T, Sumitomo Y, Masuda T, Dawson S, Shimada Y, Mayer RJ and Fujita J: The oncoprotein gankyrin binds to MDM2/HDM2, enhancing ubiquitylation and degradation of p53. Cancer Cell 8: 75-87, 2005.

7. Chen Y, Li HH, Fu J, Wang XF, Ren YB, Dong LW, Tang SH, Liu SQ, Wu MC and Wang HY: Oncoprotein p28 GANK binds to RelA and retains NF-kappaB in the cytoplasm through nuclear export. Cell Res 17: 1020-1029, 2007.

8. Zheng T, Hong X, Wang J, Pei T, Liang Y, Yin D, Song R, Song X, Lu Z, Qi S, et al: Gankyrin promotes tumor growth and metastasis through activation of IL-6/STAT3 signaling in human cholangiocarcinoma. Hepatology 59: 935-946, 2014.

9. Fu J, Chen Y, Cao J, Luo T, Qian YW, Yang W, Ren YB, Su B, Cao GW, Yang Y, et al: p28GANK overexpression accelerates hepatocellular carcinoma invasiveness and metastasis via phosphoinositol 3-kinase/AKT/hypoxia-inducible factor-1 $\alpha$ pathways. Hepatology 53: 181-192, 2011.

10. Man JH, Liang B, Gu YX, Zhou T, Li AL, Li T, Jin BF, Bai B, Zhang HY, Zhang WN, et al: Gankyrin plays an essential role in Ras-induced tumorigenesis through regulation of the RhoA/ROCK pathway in mammalian cells. J Clin Invest 120: 2829-2841, 2010.

11. Dong LW, Yang GZ, Pan YF, Chen Y, Tan YX, Dai RY, Ren YB, Fu J and Wang HY: The oncoprotein p28GANK establishes a positive feedback loop in $\beta$-catenin signaling. Cell Res 21: 1248-1261, 2011 
12. Zhang J, Yang Y, Zhang Z, He Y, Liu Z, Yu Y, Wu S, Cai B and Feng Y: Gankyrin plays an essential role in estrogen-driven and GPR30-mediated endometrial carcinoma cell proliferation via the PTEN/PI3K/AKT signaling pathway. Cancer Lett 339: 279-287, 2013.

13. Mizuno H, Kitada K, Nakai K and Sarai A: PrognoScan: A new database for meta-analysis of the prognostic value of genes. BMC Med Genomics 2: 18, 2009.

14. Tang Z, Li C, Kang B, Gao G, Li C and Zhang Z: GEPIA: A web server for cancer and normal gene expression profiling and interactive analyses. Nucleic Acids Res 45: W98-W102, 2017.

15. Guo Q, He Y, Sun L, Kong C, Cheng Y and Zhang G: In silico detection of potential prognostic circRNAs through a re-annotation strategy in ovarian cancer. Oncol Lett 17: 3677-3686, 2019

16. Keen JC and Moore HM: The genotype-tissue expression (GTEx) project: Linking clinical data with molecular analysis to advance personalized medicine. J Pers Med 5: 22-29, 2015.

17. Silverberg SG: Histopathologic grading of ovarian carcinoma: A review and proposal. Int J Gynecol Pathol 19: 7-15, 2000.

18. Pecorelli S, Benedet JL, Creasman WT and Shepherd JH: FIGO staging of gynecologic cancer. 1994-1997 FIGO committee on gynecologic oncology. international federation of gynecology and obstetrics. Int J Gynaecol Obstet 65: 243-249, 1999

19. Chen J, Bai M, Ning C, Xie B, Zhang J, Liao H, Xiong J, Tao X, Yan D, Xi X, et al: Gankyrin facilitates follicle-stimulating hormone-driven ovarian cancer cell proliferation through the PI3K/AKT/HIF-1 $\alpha /$ cyclin D1 pathway. Oncogene 35: 2506-2517, 2015.

20. Meng Y, He L, Guo X, Tang S, Zhao X, Du R, Jin J, Bi Q, Li H, Nie Y, et al: Gankyrin promotes the proliferation of human pancreatic cancer. Cancer Lett 297: 9-17, 2010.

21. Bai Z, Tai Y, Li W, Zhen C, Gu W, Jian Z, Wang Q, Lin JE, Zhao Q, Gong W, et al: Gankyrin activates IL-8 to promote hepatic metastasis of colorectal cancer. Cancer Res 73: 4548-4558, 2013
22. Ortiz CM, Ito T, Tanaka E, Tsunoda S, Nagayama S, Sakai Y, Higashitsuji H Fujita J and Shimada Y: Gankyrin oncoprotein overexpression as a critical factor for tumor growth in human esophageal squamous cell carcinoma and its clinical significance. Int J Cancer 122: 325-332, 2010.

23. Zhen C, Chen L, Zhao Q, Liang B, Gu YX, Bai ZF, Wang K, $\mathrm{Xu}$ X, Han QY, Fang DF, et al: Gankyrin promotes breast cancer cell metastasis by regulating Racl activity. Oncogene 32: 3452-3460, 2013

24. Qin X, Wang X, Liu F, Morris LE, Wang X, Jiang B and Zhang Y: Gankyrin activates mTORC1 signaling by accelerating TSC2 degradation in colorectal cancer. Cancer Lett 376: 83-94, 2016.

25. Lloyd K: The resurgence of platinum-based cancer chemotherapy. Nat Rev Cancer 7: 573-584, 2007.

26. Sun W, Ding J, Wu K, Ning BF, Wen W, Sun HY, Han T, Huang L, Dong LW, Yang W, et al: Gankyrin-mediated dedifferentiation facilitates the tumorigenicity of rat hepatocytes and hepatoma cells. Hepatology 54: 1259-1272, 2011.

27. Qian YW, Chen Y, Yang W, Fu J, Cao J, Ren YB, Zhu JJ, Su B, Luo T, Zhao XF, et al: p28 GANK prevents degradation of oct 4 and promotes expansion of tumor-initiating cells in hepatocarcinogenesis. Gastroenterology 142: 1547-1558, 2012.

28. Mine H, Sakurai T, Kashida H, Matsui S, Nishida N, Nagai T, Hagiwara S, Watanabe T and Kudo M: Association of Gankyrin and Stemness factor expression in human; Colorectal cancer. Dig Dis Sci 58: 2337-2344, 2013

29. Dai RY, Chen Y, Fu J, Dong LW, Ren YB, Yang GZ, Qian YW, Cao J, Tang SH, Yang SL and Wang HY: p28GANK inhibits endoplasmic reticulum stress-induced cell death via enhancement of the endoplasmic reticulum adaptive capacity. Cell Res 19: 1243-1257, 2009.

30. Luo T, Fu J, Xu A, Su B, Ren Y, Li N, Zhu J, Zhao X, Dai R, Cao J, et al: PSMD10/gankyrin induces autophagy to promote tumor progression through cytoplasmic interaction with ATG7 and nuclear transactivation of ATG7 expression. Autophagy 12: 1355-1371, 2016. 